\title{
KIRJOITUS
}

JOUKO KARJALAINEN

\section{Nälkävuosista koronakriisiin}

T eipäjonot ovat edelleen arkipäivää Suomessa. Väliaikaiseksi tarkoitetusIta ruoka-avusta on muovautunut 30 vuoden projekti. Suomalaiset leipäjonot nousivat 1990-luvulla ryminässä kaikkien tietoisuuteen, ulkomaita myöden ja kokivat uuden tulemisen nyt koronakriisin oloissa. Vaikka ruoka-apua oli ollut jo aikaisemmin muun muassa asunnottomien päiväkeskuksissa, 1990-luvun alussa syvän talouslaman oloissa ne saivat uuden muodon ja mittaluokan. Virallinen Suomi, viranomaiset ja useimmat ammattilaiset, myös iso osa seurakuntadiakonian toteuttajista suhtautuivat ilmiöön varsin kielteisesti. Diakonian piiristä tosin löytyi myös monta ymmärtäjää, jotka eivät katsoneet ruoka-avun olevan laman seurausten "väärä sammutusväline".

Nälkä tuli julkisen keskustelun sanastoon vuoden 1990 alun laman seurauksia selvittäneiden sosiaali- ja terveysministeriön tutkimushankkeen ja etenkin vuonna 1993 julkaistun uusintakyselyn saaman mediahuomion myötä. Joulukuussa 1993 silloinen sosiaali- ja terveysministeri kiisti koti- ja ulkomaisen median nälkäongelman olemassaolon. Tuo oli siitä lähtien julkistoimijoiden ja monen muun instituution enemmän tai vähemmän julkilausuttu linja. Kirkon ruokapankit aloittivat vuonna 1995 Tampereella ja Kirkon ruokapankkityöryhmä 1996. Ruokapankit olivat myös Yhteisvastuukeräyksen kohteena vuonna 1997. Ruokapankkityöryhmän aloitteesta koottiin laajapohjainen Nälkä-ryhmä (1997-1998), joka oli vaikuttamassa köyhyyttä koskevalla kirjauksella Lipposen kakkoshallituksen ohjelmaan. Kirjaus oli ryhmän laajapohjaisuudesta johtuen kovin yleisluonteinen, eikä sisältänyt mitään konkreettisia toimenpiteitä. Niitä toki löytyi Nälkä-ryhmän asiantuntijaryhmän laatimasta taustamuistiosta. Osa ehdotuksista päätyi Lipposen kakkoshallituksen "Köyhyyspakettiin”. Köyhyyttä niillä ei ratkaistu, kuten tiedämme 
- ja tiesimme silloinkin. Nälkävuosien voi katsoa sen jälkeen päättyneen, sillä "nälkä" sana ei ollut enää (keskeinen) osa köyhyyskeskustelua.

Suomi on osallistunut EU:n vähävaraisille asukkailleen suunnatun elintarvikeavun ohjelmaan alusta asti. Päätöstä ei osallistumisesta tuolloin 1996 suinkaan tehnyt sosiaali- ja terveysministeri vaan maa- ja metsätalousministeri. Paikallisseurakunnat ja evankelis-luterilaisen kirkon ruokapankit ovat olleet yksi keskeinen jakeluorganisaatio muutamien valtakunnallisten järjestöjen lisäksi. Seurakuntadiakonian kenttä on myös jakautunut ruoka-avun suhteen asiassa. Hävikki- tai ylijäämäruoan jakelussa on tällä hetkellä useimpien arvioiden mukaan noin 1000 paikallistoimijaa, osa valtakunnallisten organisaatioiden jäseniä, mutta myös iso joukko toimii myös itsenäisesti.

Viime vuosien kehityksen perusteella myös ruoka-aputoiminnan saama julkinen hyväksyntä on ollut kasvussa. Sosiaali- ja terveysministeriö nimittäin kohdensi ensi kertaa vuonna 2016 eduskunnan päätöksellä 765000 euroa tukea ruoka-avun toimijoiden ryhmittymälle apujärjestelmän kehittämiseen ja ylläpitämiseen. Vuonna 2017 käynnistynyt Yhteinen keittiö -hanke on samoin saanut tukea Sosiaali- ja terveysministeriöltä. Kyseessä oli Kirkkohallituksen koordinoima kaksivuotinen hanke, jonka aikana jokaiseen maakuntaan perustettiin vähintään kaksi Yhteisen keittiön nimeä matalan kynnyksen kohtaamispaikkaa. Pari kolme niistä toimii edelleen. Lukuisat kunnat ovat tavalla tai toisella olleet mukana tukemassa paikallisia työttömien yhdistyksiä, seurakuntia ja muita toimijoita. Koronakriisi lisäsi yhteistoimintaa entisestään.

Eduskunnan valtiovarainvaliokunnan katsoi (20/2019), että "ruoka-aputoiminnan rahoitus on kuitenkin saatava kestävälle pohjalle siten, ettei se ole eduskunnan vuosittain myöntämän lisärahoituksen varassa. Toimintaa tulee kehittää esim. parantamalla tukijärjestelmien toimivuutta ja niveltämällä toiminta paikallisiin sosiaalipalveluihin." Sosiaali- ja terveysministeriö tilasi Pääkaupunkiseudun sosiaalialan osaamiskeskus Soccalta asiasta selvityksen syksyllä 2020. Raportti valmistui helmikuussa (Karjalainen ym., 2021) ja se keskittyy ruoka-aputoiminnan arviointiin sekä yhteistoimintaan niin kuntien kanssa kuin järjestötoimijoiden kesken. Raportissa ei selvitetä perusturvan riittävyyttä tai ratkaista muitakaan tilanteita, jotka aiheuttavat ruoka-avun tarvetta.

Vapaaehtoistyöhön perustuva moni-ilmeinen ruoka-avun missio on luonut ilmiön, jonka pitkäikäisyyttä ja suosiota ei ole syytä ihmetellä. Ruoka on 
kiitollinen avustustoiminnan kohde, sillä avun tarve näyttää useimmiten ilmeiseltä ja vapaaehtoinen näkee avun menevän välittömästi perille. Lisäksi jakoa toteuttavat ovat 1990-luvun alusta asti korostaneet sitä, että ainakaan heidän jakamansa elintarvikkeet eivät joudu kaatopaikalle. Useiden ruoka-apua jakavien mukaan apu on hakijoille "elintärkeää", toiset taas arvioivat kävijöiden voivan näin käyttää vähät varansa muihin menoihinsa. Isoissa kaupungeissa tarjontaa on niin paljon, että ruoka-apua hakeva voi vähentää kaupasta ostettujen elintarvikkeiden hankintaa merkittävästikin.

Koronakriisi osoitti, että poikkeusoloihin varautumisessa oli satojen tuhansien ruokakassien kokoinen aukko. Samankaltainen tilanne oli 1990-luvun lamankin aikaan, jolloin herättiin aika karusti suorastaan hätäavun tarpeeseen. Molempien kriisien yhteydessä ruoka-apujärjestelmä osoittautui yhdeksi tavaksi varmistaa merkittävän ihmisjoukon ruokaturvaa. "Varmuusvarasto" tarkoittaa tässä tapauksessa ruokakauppojen, elintarviketeollisuuden, tukkuliikkeiden ja ruoka-aputoimijoiden muodostama ketjua, joka takaa varmuusvaraston jatkuvan kierron erotuksena perinteisten varmuusvarastojen staattisempaan varastointiin. Koronakriisi osoitti myös sen, että poikkeusoloissa muustakin voi tulla pulaa kuin vessapaperista: kaikkea ei saa rahalla, josta huono-osaisilla on sitä paitsi aina pulaa.

Julkisuudessa ruoka-apu on pelkistetty leipäjonoiksi, perin virheellisesti, ja ehkä tarkoitushakuisesti. Niitä kun on helpompi vastustaa kuin vaikkapa diakonian järjestämiä yhteisiä ruokailuja. Raportissamme tunnistimme muun muassa 1) ruokajonot, 2) ruoka-apu osana muuta toimintaa, 3) kotiinkuljetuspalvelut, jolla on ollut erityinen merkitys korona-aikana, 4) bävikkimarket, 5) some-ryhmät, kouluista ja ravintoloista yli jäävät 6) valmiit ruoka-annokset ja 7) yksittäiset tapahtumat kuten yksinäisten joulujuhlat. Ruoka-apua on tosiaan moneksi.

Kaikki toimijat kokevat aiheellisesti huolta perusturvan riittävyydessä, mutta useimmat haastattelemamme näkevät, että tuskin edes perustulo poistaisi ruoka-apuilmiötä. Se tarjoaa monelle pientä tai jopa joissain tapauksissa merkittävääkin mahdollisuuksia muihin hankintoihin. Lisäksi se on aina ollut paljon muutakin kuin leipäjonoja ja toiminta on monipuolistunut etenkin 2010-luvulla. Yhä useammin se on yhteisruokailuja, yhteisöllisyyttä ja yhteenkuuluvuutta lisäävää toimintaa, vertaistukea, työllistämistä ja hävikkiterminaaleja. Kävijöitä on satojatuhansia vuosittain ja samalla ruokahävikki vähenee miljoonilla kiloilla. Uutena ilmiönä on havaittavissa, että hävikki- ja 
ylijäämäruoasta on tullut suorastaan trendi, joka on vähentänyt ilmaisjakeluun saatavien elintarvikkeiden määrää. Se saattaa olla ruoka-aputoiminnan tulevaisuuteen vaikuttavampi tekijä kuin vuosikymmeniä toistettu ja ilman selkeitä toimenpide-ehdotuksia jäänyt osin osoitteeton vaatimus siitä, että "sellaista apua ei hyvinvointivaltiossa pitäisi olla".

Leipäjonoista käyty 30-vuotinen sanasota liittyy ainakin näennäisesti suhtautumiseen pohjoismaiseen hyvinvointivaltioon, vaikka vahvat tunnelataukset viittaavat myös piilotettuihin motiiveihin. Julkilausuttujen tarkoitusperien ääripäissä on kaksi omalla tavallaan fundamentalistisesti sosiaaliturvapolitiikkaan suhtautuvaa argumentointimallia. Molemmissa äärilähtökohdissa fokus on ollut, jos nyt ei aivan hukassa, niin ainakin vahvasti toivotun lopputuloksen sumentama. Toisaalla ovat he, joiden mielestä ruoka-apu ei kerta kaikkiaan sovi hyvinvointivaltioon, ja siitä olisi pikimmiten pitänyt pästävä eroon. Voinee sanoa, että ilmiön kieltämisen projekti on toiminut ilmeisen heikosti. Tätä näkemystä edustavat katselevat ruoka-apua usein kaukaa. Toisaalta moni käytännön toimija jaksaa yhä toistella sitä, että leipäjonoista päästään eroon vain perusturvan merkittävällä korotuksella. Saamiemme vastausten perusteella näyttää siltä, että useimmat ruoka-apua jakavat eivät usko perustulonkaan poistavan ruoka-apua.

Kyselymme vastausten perusteella näyttää siltä, vuosikymmenien saatossa kumpikin ääriajattelu on vähentynyt. Ruoka-avun kanssa on opittu elämään ja näyttää siltä, että hyvin järjestettynä se voi sittenkin sopia hyvinvointivaltioon, kunhan sillä ei jatkossakaan korvata julkista sosiaaliturvaa. Se on tärkeä hyvinvoinnin vajeiden tunnistaja, mutta ei kuitenkaan köyhyysmittari. Selvityksemme osoitti myös sen, että järjestämistavoissa on vielä paljonkin kehitettävää. Tosin ajankohta oli koronakriisin vuoksi mahdollisimman huono kovin pitkälle meneville johtopäätöksille.

Selvityksessä ehdotetaan kolmea, osittain ajallisesti vaihtoehtoista etenemistapa kehittää ja rahoittaa ruoka-apua matalan kynnyksen hyvinvoinnin ja terveyden edistämisen toimintana. Vuodelle 2021 on jo myönnetty entisillä ehdoilla runsas miljoona euroa kolmelle valtakunnalliselle toimijalle. Vuoden 2022 alusta voidaan jatkaa entisellään sosiaali- ja terveysministeriön koordinoimana, jos niin poliittisesti päätetään. Selvityksemmekin kuitenkin osoitti, että ruoka-apu sopii huonosti kaukaa johdetuksi. Niinpä toisena siirtymävaiheen vaihtoehtona esitämme järjestöjen koordinoimaa hallintamallia, jossa rahoitus tulisi edelleen erillisrahoituksena sosiaali- ja terveysministeriön 
kautta. Kunnat ovat eri tavoin mukana ruoka-aputoiminnassa ja niiden rahoitus on moninkertainen nykyiseen ja tulevaankin valtionrahoitukseen verrattuna.

Kolmas vaihtoehto on, että kunta- ja hyvinvointialuekoordinaatio astuisi kuvaan sote-uudistuksen jälkeen. Tällöin uudistuksen puitteissa moni asia pitää sovittaa uusiin hallintorakenteisiin. Soten järjestämislaki ei säädä tarkasti vastuunjaosta hyvinvoinnin ja terveyden edistämisestä kuntien ja alueiden välillä, joten ruoka-aputoimijoiden yhteistoiminta on välttämätöntä. Tätä kirjoitettaessa toukokuussa 2021 näyttää siltä, että Soccan raportit keskeiset ehdotukset ovat toteutumassa. Ruoka-aputoimijoiden itse toteuttaman kehittämishankkeen käynnistymisen voi nähdä uutena mahdollisuutena ruoka-avun ja leipäjonojen seuraaville askeleille yhteistyössä alueellisen ja paikallisen rakenteellisen ja yhteisöllisen sosiaalityön kanssa.

\section{Kirjallisuus}

Karjalainen, J., Hossain-Karhu, R, Marjamäki, R. \& Sinkkonen, A. (2021). Ruoka luo ybteyden. Ruoka-apu hyvinvointivaltiossa. Socca, Pääkaupunkiseudun sosiaalialan osaamiskeskus. https://stm.fi/-/selvitys-ruoka-avun-tilanteesta-ja-jarjestamisesta-valmistunut - Viitattu 25.5.2021. 